\title{
МЕТОДОЛОГІЯ ПІДГОТОВКИ ЮРИСТІВ: ДОСВІД КРАЇН ЄВРОПЕЙСЬКОГО СОЮЗУ ТА ЙОГО ВПРОВАДЖЕННЯ В УКРАЇНІ
}

\author{
Чигрина Г. Л.
}

\section{ВСТУП}

Людина, іiї життя і здоров'я, честь і гідність, недоторканність і безпека найвища соціальна цінність в Україні. Ми творимо Україну вільною, заможною, безпечною державою, де панує право, де держава захищає громадян i суспільство, де кожен може реалізувати свої таланти та здібності ${ }^{1}$.

Юрист - це професіонал, який має фундаментальні та спеціальні правові знання, глибоко переконаний у винятковому призначенні права і законності для суспільства, кваліфіковано користується юридичним інструментарієм при розв'язанні юридичних проблем в ім'я захисту прав і законних інтересів громадян, забезпечуючи національну безпеку України ${ }^{2}$.

Між тим, як показали дослідження всеукраїнського щотижневого професійного видання «Юридична газета online» (далі - «ЮГ»), щороку дедалі більше українських студентів роблять вибір на користь отримання юридичної освіти за кордоном, серед яких чільне місце належить країнам Європейського Союзу (далі - ЄС). Якщо ще якихось десять років тому українські юристи із закордонними юридичними дипломами зазвичай не бачили свою подальшу кар'єру поза вітчизняною фірмою, тепер це поступово змінюється ${ }^{3}$.

Нарівні із юридичною компанією в Україні молоді юристи також обирають для себе можливість залишитися у країні навчання, працювати у громадському секторі, підприємницьких ініціативах чи програмах міжнародної допомоги. Жоден із опитаних «ЮГ» молодих юристів не назвав такий вибір випадковим.

Мета кореспондентів «ЮГ» - на прикладі «персональних історій успіху» респондентів допомогти потенційним студентам і юристам-початківцям зважити власні «за» і «проти», перспективи професійного розвитку та розкрити механізми здобуття правової освіти у західному світі.

\footnotetext{
${ }^{1}$ Про рішення Ради національної безпеки і оборони України від 14 вересня 2020 р. «Про Стратегію національної безпеки України» : Указ Президента України від 14 вересня 2020 р. № 392/2020. URL: https://zakon.rada.gov.ua/laws/show/392/2020\#Text (дата звернення: 11.11.2020).

2 Престиж юридичної професії. URL: https://prezi.com/admedxvk14bk/presentation/ (дата звернення: 11.11.2020).

${ }^{3}$ Study abroad: закордонна освіта очима українських правників. URL: https://yur-gazeta.com/ publications/practice/inshe/study-abroad-zakordonna-osvita-ochima-ukrayinskih-pravnikiv.html (дата звернення: 11.11.2020).
} 
Мета нашої роботи - проаналізувати досвід підготовки юристів у країнах ЄC i сформулювати методичні рекомендації щодо можливості його впровадження в Україні.

Поставлена мета зумовила постановку та вирішення таких завдань:

- вивчити європейський досвід організації системи юридичної освіти;

- порівняти особливості процесу підготовки юристів в Україні та країнах $€ C$;

- сформулювати методичні рекомендації щодо можливості впровадження європейського досвіду організації юридичної освіти у систему підготовки юристів в Україні.

\section{1. Свропейські тенденції розвитку юридичної освіти}

Сучасний європейський досвід організації системи юридичної освіти та зміст освітніх програм проаналізуємо, використовуючи дослідження «ЮГ», про яке ми згадували у вступі до нашої роботи. Так, респонденти, у ролі яких виступили молоді юристи України, поділилися із журналістами «ЮГ» своїми думками щодо:

- рівня здобутої юридичної освіти в Україні та за кордоном;

- факторів, які доцільно враховувати у виборі майбутнього навчального закладу (крізь призму особистого досвіду та на прикладі їхніх університетів);

- впливу закордонної юридичної освіти на їх подальше кар'єрне зростання.

Так, експерт із пенітенціарних питань Міжнародного комітету Червоного Хреста Михайло Іскра, який отримав ступінь LL.M. у праві Європейського Союзу ${ }^{4}$ в College of Europe (Бельгія), а доти навчався в Україні в Національному юридичному університеті ім. Ярослава Мудрого та «Києво-Могилянській академії», радить не забувати, що магістерські програми за кордоном мають доволі вузьку спеціалізацію (business law, intellectual property). Тому він рекомендує потенційним абітурієнтам обирати заздалегідь, за якою спеціалізацією $\epsilon$ бажання навчатися, таким чином підбираючи список закордонних вишів, де $\epsilon$ така фахова підготовка. Крім того, експерт радить враховувати і можливість отримання гранту на навчання. Так, однорічна програма Михайла, 3 гуртожитком у Бельгії, коштувала 24 тис. євро. Отже, при виборі треба дивитися на перспективу отримання стипендії. Зазвичай інформація щодо таких стипендій є на сайтах навчальних закладів. Окрім того, існують фонди, які можуть оплатити навчання.

\footnotetext{
${ }^{4}$ Магістр європейського права (скорочено LL.M. Eur., від лат. Magister Legum Europae, англ. Master of European Law) - другий вищий академічний ступінь кваліфікації. Це один зі спеціальних LL.M. ступенів, який здобувається за результатами успішного завершення навчальної програми 3 європейського права, а також написання та захисту магістерскої работи на відповідну тему.
} 
У випадку Михайла Іскри система навчання у Коледжі Свропи дещо нагадувала заочну форму: викладачі прилітали до студентів із різних університетів 3-4 рази на семестр, проводили заняття повні 2 дні, давали дуже об'ємне «домашнє завдання» й у кінці семестру приймали екзамен. Заняття були сумішшю лекції та практичного заняття: викладач робив презентацію по темі, а пізніше давав студентам практичне завдання для вирішення або свою лекцію поєднував із доповідями та презентаціями студентів, які отримували завдання заздалегідь. За доповідь чи презентацію студент не отримує ніяких балів - оцінка формується виключно за результатом екзамену.

Така система, на думку молодого українського юриста, $\epsilon$ дуже ефективною для магістратури, оскільки студент опановує матеріал у бібліотеці та витрачає час викладача (і свій час також) на обговорення складних і незрозумілих моментів та вирішення практичних завдань. Однак він не впевнений, що така система була б ефективною для підготовки бакалаврів. Екзамени на правничому факультеті College of Europe yci письмові, а імена студентів зашифровані, тобто викладач, оцінюючи роботу, не знає, чий текст перевіряє ${ }^{5}$.

На нашу думку, система оцінювання знань студентів-магістрів бельгійського коледжу, безсумнівно, прогресивна, вона не залишає місця корупції. Саме 3 цієї причини окремі українські виші не дуже поспішатимуть їі запроваджувати. Як показує власний досвід, не всі сучасні українські навчальні заклади ставлять за мету надання якісної освіти та підвищення свого авторитету. Для окремих вишів важливо, щоб більше студентів «шикувалися в чергу» за дипломами, які вони видають, тож нехтують якістю викладання та грунтовністю наданих знань.

Святослав Грігораш, котрий здобув диплом бакалавра у Дніпровському університеті імені Олеся Гончара і згодом навчався на магістерській програмі з міжнародного права та права ЄС Вільнюського університету (Литва), відзначив дві позитивні риси, які, на його погляд, є ефективними і допомагають студентам краще засвоїти матеріал. Перша - методика проведення лекцій: замість нудного лектора, котрий читає сухий академічний текст, студент отримує «живе» спілкування. Друга риса черговість вивчення предметів. Студенти магістратури Вільнюського університету вивчають одну дисципліну протягом 2-3 тижнів і одразу здають із неї екзамен, що позитивно впливає на засвоюваність навчального матеріалу і не «розпилює» студента під час сесії відразу «на все» ${ }^{6}$.

\footnotetext{
${ }^{5}$ Study abroad: закордонна освіта очима українських правників. URL: https://yur-gazeta.com/ publications/practice/inshe/study-abroad-zakordonna-osvita-ochima-ukrayinskih-pravnikiv.html (дата звернення: 11.11.2020).

${ }^{6}$ Там само.
} 
На нашу думку, це цікавий досвід, який кардинально відрізняється від системи організації навчального процесу в українських вишах. Для України традиційними залишаються сесії, на які виносяться декілька екзаменів i заліків. За такого підходу дійсно будь-який студент, і не тільки майбутній юрист, має колосальне навантаження, яке не завжди сприяє якості засвоєння матеріалу. Навпаки, багато студентів стверджують, що, як відповідь на перевантаження, захисна реакція мозку проявляється у тому, що вони після сесії більшу частину того, що було «зазубрено» протягом останньої ночі перед екзаменом, забувають.

Святослав позитивно відгукується про рівень підготовки українських студентів, котрі навчалися з ним в університеті в Литві. Усі вони володіли англійською мовою, більшість мала практичний досвід роботи та були випускниками провідних українських вишів.

Погоджуємося 3 респондентом у тому, що досконале знання іноземної мови, зокрема англійської, відкриває шлях до навчання за кордоном, але опанувати на належному рівні іноземну мову можна, тільки докладаючи до цього власні зусилля. Для вивчення мови потрібен час і неабияке бажання, не говорячи вже про додаткові кошти. Як вихід, для оволодіння іноземною мовою можна використовувати ресурси Інтернету, але найкращим мотиватором для вивчення іноземної мови, на нашу думку, $\epsilon$ особисте бажання i можливість отримати юридичну освіту за межами України (наприклад, стати переможцем конкурсу й отримати грант на навчання за кордоном тощо).

Ніка Аврамчук, яка на час опитування (2018р.) здобувала ступінь магістра у Києво-Могилянській академії та раніше провела повний навчальний рік за обміном у Ягелонському університеті у Кракові (Польща), розповіла, що ніхто не змушував студентів ходити на пари, викладачу було байдуже, як ти отримаєш знання, а лекції та семінарські заняття не $є$ обов'язковими як такі (екзамен можеш здати і без них). Підручники були більш комплексними, зокрема 3 права $Є С$ мали тільки один підручник з усіма важливими питаннями та кейси додатково. Крім того, в університеті діє електронна система запису на дисципліни та взагалі можливість отримання усіх адміністративних послуг, що дуже зручно для студента?

Такий підхід контрастує з організацією навчального процесу в Україні взагалі й організацією підготовки майбутніх юристів зокрема. Для організації навчального процесу в Україні, на жаль, у переважній більшості вишів традиційними залишаються контроль за відвідуванням занять студентами,

\footnotetext{
Study abroad: закордонна освіта очима українських правників. URL: https://yur-gazeta.com/ publications/practice/inshe/study-abroad-zakordonna-osvita-ochima-ukrayinskih-pravnikiv.html (дата звернення: 11.11.2020).
} 
журнали обліку процесу «відпрацювання» (перездачі) пропущених семінарських і практичних занять тощо. Все це створює додаткове навантаження на викладача, забирає час, який викладач може більш ефективно використати для підготовки до проведення лекційних, семінарських i практичних занять. Студентів же така організація навчального процесу «слабо» мотивує до навчання. Як показує практика, студентів не спиняє навіть встановлена деякими вишами оплата за повторну перездачу екзаменів (заліків). Здебільшого за повторну перездачу екзамену (заліку) студент розраховується грошима, не заробленими власною працею, а взятими у батьків чи інших «спонсорів». На нашу думку, українським вишам давно слід переглянути організацію навчального процесу, методи контролю рівня знань студентів і майстерність викладання навчальних дисциплін, зокрема юридичних, а не удосконалювати методи контролю відвідування занять студентами. Така політика насамперед повинна заохочуватися, підтримуватися та популяризуватися Міністерством освіти і науки України.

Порівнюючи організацію навчального процесу в Україні та Польщі, Марина Мокрецька, випускниця юридичного факультету КНЕУ ім. Вадима Гетьмана, яка має досвід навчання за стипендією Уряду Польщі на магістерській програмі Studium Europy Wschodniej у Варшавському університеті (Польща), розповіла, що їй, як і іншим українським студентам, потрібен був деякий час для адаптації до процесу навчання, у т. ч. мовної8

Як позитив, Марина зазначила, що Варшавський університет дає кожному студенту можливість вивчити будь-яку іноземну мову за рахунок навчального закладу.

Підготовка юристів, як і випускників інших спеціальностей, у Варшавському університеті проходить за принципом, що респондент визначила так: «Викладач лише вказує дорогу до знань, а нагромаджувати та розширювати їх повинен виключно сам студент». Весь процес навчання розрахований на самостійне вивчення та поглиблення своїх знань, виключно на особистому бажанні та мотивації.

Бібліотека у Варшавському університеті, за словами Марини Мокрецької, $є$ «другим домом» для студента. Жодного підручника тут не видається, є так звані «силабуси», де поряд 3 описом самого предмета вказується література, необхідна до вивчення. Інколи буває, що деякі книжки недоступні для читання поза бібліотекою. Через це під час екзаменів бібліотека працює цілодобово, щоб кожен мав можливість прийти й ознайомитися з необхідною літературою.

\footnotetext{
8 Study abroad: закордонна освіта очима українських правників. URL: https://yur-gazeta.com/ publications/practice/inshe/study-abroad-zakordonna-osvita-ochima-ukrayinskih-pravnikiv.html (дата звернення: 11.11.2020).
} 
Саме обов'язковість самостійного вивчення матеріалу Марина Мокрецька радить додати до навчального процесу в українських вишах. На iï думку, надання викладачем повного систематизованого викладу необхідного матеріалу - це перевага української системи освіти. Такий підхід, з одного боку, економить час, витрачений на сидіння в бібліотеці, але з іншого - не сприяє розвитку навичок самостійної роботи, систематизації й аналізу отриманої інформації. Крім того, Марина відзначає, що у Варшавському університеті вважається досить дивним, якщо студент обмежується виключно заняттями та не бере участі у жодних конференціях, практикумах i семінаріумах, яких тут проводиться чимало .

На жаль, не в усіх університетах України є така традиція. Із власного досвіду можемо констатувати, що тільки незначна частина студентів (менше $15 \%$ від загальної кількості студентів вишу) відвідують конференції, круглі столи, наукові семінари тощо. У чому причина - важко сказати. Частково, на нашу думку, одноманітність і типовість (стандартність) форм проведення цих заходів, а частково - нерозуміння студентами важливості поза аудиторних заходів для їхнього інтелектуального розвитку та фахового становлення.

Наталя Тужеляк, котра захистила кандидатську дисертацію за правничим напрямом у Національній академій внутрішніх справ, розповіла «ЮГ» про свій досвід вступу до Університетського коледжу Лондону та навчання у ньому. Фокусом навчання Наталі було вивчення арбітражу, комерційного вирішення спорів, а також міжнародного приватного та публічного права.

За іiї словами, на рівні магістратури надзвичайно важливою є можливість студентів обирати предмети до вивчення. Протягом першого тижня навчання студенти відвідують вступний курс, на якому представлені всі модулі, які пропонує університет. Студент має можливість послухати 5-хвилинні лекції від професора, котрий викладатиме курс, познайомитися, поставити запитання. Це однозначно допомагає зробити правильний вибір ${ }^{10}$.

Другою відмінністю від вітчизняного підходу до юридичної освіти Наталя Тужеляк називає кількість модулів (навчальних дисциплін), оскільки іiі магістерська програма протягом року складалася із вивчення всього 4 предметів (із 30 кредитів кожен) i написання магістерської роботи. Кількість предметів у додатках до українських дипломів, які мала Наталя, не раз дивувала англійських колег і ставала предметом довгих пояснень і дискусій. Зменшення кількості модулів, на думку респондентки, тільки сприятиме покращенню якості української правничої освіти.

\footnotetext{
9 Study abroad: закордонна освіта очима українських правників. URL: https:/yur-gazeta.com/ publications/practice/inshe/study-abroad-zakordonna-osvita-ochima-ukrayinskih-pravnikiv.html (дата звернення: 11.11.2020).

10 там само.
} 
Повністю погоджуємося 3 висновком Наталі Тужеляк щодо необхідності включення до магістерської програми мінімальної кількості навчальних дисциплін (модулів) (на нашу думку, оптимально - не більше п'яти). Включені до програми дисципліни повинні бути максимально наближені до спеціалізації майбутнього юриста (нотаріус, адвокат, фахівець у сфері обігу цінних паперів, фінансових розслідувань тощо).

Такий підхід дозволить поглиблено вивчити запропоновані магістерською програмою навчальні дисципліни т азабезпечить фахівця-юриста саме тими знаннями, які прискорять його кар'єрне зростання.

На час проведення опитування Наталя Тужеляк продовжувала освіту у Великій Британії з метою отримання рівня бакалавра, щоб кваліфікуватися як англійський юрист. За іiі словами, бакалаврська програма для правників там складається усього 3 десяти предметів. Після цього студенти роблять вибір: стати барістером (судовим адвокатом) чи солісітером (юристом без права представляти клієнта в суді). Таким чином, відповідно до свого вибору студенти вивчають процесуальну частину протягом однорічного практичного курсу Legal Practice Course, якщо бажають стати солісітерами, або Bar Professional Training Course, якщо обрали фах барістера. Проте на цьому навчання не завершується: після навчання загальною тривалістю 4 роки студенти проходять дворічний тренінг у юридичній фірмі або однорічний тренінг в адвокатській колегії (залежно від вибору професії).

Важливим, на думку Наталі, $є$ те, що на бакалавраті британські студентиправники не вчать ані теорію держави і права, ані історію держави і права зарубіжних країн та інші «абсолютно зайві предмети». Втім, за бажання студент може вчити ці дисципліни уже в магістратурі чи докторантурі ${ }^{11}$.

На нашу думку, щодо історії держави і права зарубіжних країн ще можна погодитися - іiі вивчення на бакалавраті, можливо, і зайве, але щодо непотрібності вивчення теорії держави і права на бакалавраті категорично не погоджуємося. Теорія держави і права дає загальне уявлення про роль права у державі та $є$ корисною для формування світогляду майбутнього юриста (правника) незалежно від фаху, який він обере у майбутньому (нотаріус, адвокат, слідчий, прокурор, патентний повірений).

Позитивними вважаємо дворічні тренінги ${ }^{12}$ у юридичній фірмі або однорічні тренінги в адвокатській колегії (залежно від вибору фаху). Українським вишам, які готують майбутніх юристів, доцільно було б

\footnotetext{
11 Study abroad: закордонна освіта очима українських правників. URL: https://yur-gazeta.com/ publications/practice/inshe/study-abroad-zakordonna-osvita-ochima-ukrayinskih-pravnikiv.html (дата звернення: 11.11.2020).

12 Тренінг - це запланований процес модифікації ставлення, знання чи поведінкових навичок того, хто навчається, через набуття навчального досвіду, щоб досягти ефективного виконання в одному виді діяльності або в певній галузі.
} 
запровадити подібні тренінги. Європейський досвід використання тривалих тренінгів під час навчального процесу, на нашу думку, потребує вивчення на рівні Міністерства освіти і науки України, враховуючи, що передбачені в Україні навчальними програмами підготовки юристів нетривалі практики (стажування) не досягають поставленої мети через їх короткочасність. Тренінги мали б подвійну користь. 3 одного боку, дали б можливість визначитися із «профпридатністю» майбутнього юриста та забезпечили б участь практичних працівників (потенційних роботодавців) у становленні фахового рівня майбутніх юристів. 3 іншого - викладачі вишів, котрі забезпечують (організовують і контролюють) проходження студентами тренінгів у практичних підрозділах (юридичних фірмах, адвокатських колегіях, нотаріальних фірмах тощо), автоматично підвищували б власний фаховий рівень.

Перевірка знань у британському виші, за словами Наталі Тужеляк, є окремим питанням. Всі екзамени на рівні магістратури та бакалаврату письмові. Три питання, три години, ручка, папір, у деяких випадках - закони чи витяги із законів. Все інше потрібно знати. Списування, або академічна недоброчесність (academic dishonesty, як це називається в Англії), жорстко карається, у т. ч. виключенням з університету. Студент на екзамені не може відбутися і простими відповідями, оскільки екзаменаційні питання вимагають застосування знань до практичних ситуацій або пропонують написати критичне есе на запропоновану тему ${ }^{13}$.

Таким чином, як ми вже зазначали, європейська система освіти, зокрема юридичної, сконцентрована на двох ключових моментах: 1) забезпечення якості знань студентів (зокрема юристів), котрі закінчують університет; 2) авторитет університету як вишу, який готує конкурентоздатних спеціалістів, фахівців своєї справи. На досягнення поставленої мети століттями спрямована діяльність таких університетів. Цих університетів одиниці, і про них відомо у всьому сучасному світі (Оксфордський, Кембриджський, Карлів університет та ін.). Такі виші престижно закінчувати, і потрапити на навчання до них дуже важко. Ці університети не бояться відраховувати «недостойних» студентів, які будуть не варті диплому за рівнем отриманих знань. Щоб запросити на роботу випускників таких університетів, роботодавці шикуються в чергу.

Навчаючись права в Лондоні, за словами Наталі Тужеляк, безумовно, слід багато уваги приділяти самопідготовці. Коментарі на семінарах жодним чином не оцінюються і не впливають на фінальний результат, оскільки

\footnotetext{
${ }^{13}$ Study abroad: закордонна освіта очима українських правників. URL: https://yur-gazeta.com/ publications/practice/inshe/study-abroad-zakordonna-osvita-ochima-ukrayinskih-pravnikiv.html (дата звернення: 11.11.2020).
} 
питання для дискусій побудовані таким чином, щоб на них не було «поганої» чи «хорошої» відповіді. Все, що має значення - обгрунтування і захист своєї думки - як і в юридичній професії взагалі ${ }^{14}$.

Ми б ще додали до цього мудрого висновку, що для юриста вміння говорити, переконувати, обгрунтовувати свої думки і висновки $\epsilon$ дуже важливим. Цьому навчитися непросто. Власний 15-річний досвід слідчої роботи на різних посадах і 20-річна робота, пов'язана 3 викладанням юридичних дисциплін в університеті, дозволяють автору цієї роботи стверджувати, що тільки наполеглива самоосвіта, постійне вивчення нормативно-правових актів і матеріалів раніше вирішених юридичних справ (враховуючи коло наукових i фахових інтересів, автор роботи вивчає переважно кримінальні справи), дадуть можливість із часом навчитися юридично грамотно висловлювати свої думки, переконливо спілкуватися у колі однодумців (професіоналів, науковців), обгрунтовувати зроблені висновки при складанні юридичних документів і під час вирішення юридичних справ у судовому засіданні.

Окремо Наталя Тужеляк зупинилася на університетських бібліотеках Англії. Бібліотеки працювали в ііі університеті цілодобово. До Лондону вона ніколи у них не вчилася. Якщо врахувати, що в Англії $80 \%$ навчання - це самонавчання, то неважко зрозуміти, чому бібліотека стає другим домом студента. Так повинно стати і в Україні. Після закінчення університету, до речі, всі студенти Університетського коледжу Лондону отримують картку випускника, що дозволяє користуватися книгами й електронними ресурсами бібліотеки все життя.

Зазначене ще раз підтверджує зроблені нами висновки щодо важливості та необхідності для юристів постійного самовдосконалення та самоосвіти. Законодавство, як і життя, постійно змінюється.

Як висновок, доцільно акцентувати увагу на тому, що якість наданих юристом послуг залежить від фахового рівня самого юриста, а високий фаховий рівень пришвидшує кар'єрне зростання молодого юриста.

\section{2. Система підготовки юристів в України}

\section{та шляхи її вдосконалення}

На запит «виші України - довідник ВНЗ - спеціальність «Право»» в Інтернеті ми отримали список зі 168 навчальних закладів, які готують фахівців правничих спеціальностей (галузь знань 08 «Право» (спеціальність 081 «Право»); галузь знань 29 «Міжнародні відносини»

\footnotetext{
14 Study abroad: закордонна освіта очима українських правників. URL: https://yur-gazeta.com/ publications/practice/inshe/study-abroad-zakordonna-osvita-ochima-ukrayinskih-pravnikiv.html (дата звернення: 11.11.2020).
} 
(спеціальність 293 «Міжнародне право»); галузь знань 26 «Цивільна безпека» (спеціальність: 262 «Правоохоронна діяльність»)) ${ }^{15}$.

Як вважають провідні науковці-юристи України, розгалужена система юридичних вишів сприяє демонополізації юридичної освіти, а отже, і iі демократизації та більшій доступності, поширенню юридичних знань серед громадян України, розвитку юридичної освіченості ${ }^{16}$.

Одним із дієвих засобів удосконалення вітчизняної системи вищої освіти, зокрема юридичної, можна вважати імплементацію європейських стандартів вищої освіти до чинного законодавства України. До таких засобів доцільно віднести рекомендації Паризької конференції європейських міністрів, відповідальних за вищу освіту. 24-25 травня 2018 р. конференцією була прийнята оновлена загальна Рамка кваліфікацій у Європейському просторі вищої освіти (далі - $Є$ ПВО) $)^{17}$, яка включає загальні характеристики короткого циклу, першого, другого та третього циклів для кожного циклу на основі результатів навчання і компетентностей, а також кредитні діапазони в короткому циклі, першому та другому циклах. Міністри взяли на себе обов'язок розробити національні рамки кваліфікацій, сумісні із загальною Рамкою кваліфікацій у СПВО.

Але, на нашу думку, до процесу реформування системи освіти, у т. ч. юридичної, необхідно підходити системно і виважено, враховуючи національні традиції. Яскравим прикладом непродуманого підходу до реформування вищої освіти є Закон України «Про вищу освіту» ${ }^{18}$, який, будучи прийнятим у липні 2014 р., станом на листопад 2020 р. вже має понад три десятки змін.

Законом декларується покращення вищої освіти шляхом встановлення основних правових, організаційних, фінансових засад функціонування системи вищої освіти, створення умов для посилення співпраці державних органів i бізнесу із закладами вищої освіти на принципах автономії закладів вищої освіти, поєднання освіти 3 наукою та виробництвом 3 метою підготовки конкурентоспроможного людського капіталу для високотехнологічного та інноваційного розвитку країни, самореалізації особистості, забезпечення потреб суспільства, ринку праці та держави у кваліфікованих фахівцях. В Україні відсутні як дієвий механізм реалізації перелічених положень, так і кваліфіковані кадри викладачів, котрі були б спроможні задовольнити потреби сучасних студентів.

\footnotetext{
${ }^{15}$ Довідник BH3. URL: http://osvita.ua/vnz/guide/search-17-0-0-147-0.html (дата звернення: 12.11.2020).

16 Тертишник В.М. Кримінальний процес України. Загальна частина : підручник. Київ : Алерта, 2014. С. 92.

17 Додаток III: Загальна Рамка кваліфікацій Свропейського простору вищої освіти (редакція 2018 р.) URL: https://www.google.com/search?q=chrome..69i57\&sourceid=chrome\&ie=UTF-8 (дата звернення: 14.11.2020).

${ }^{18}$ Про вищу освіту : Закон України від 1 липня 2014 р. № 1556-VII (із змінами і доповненнями). URL: https://zakon.rada.go3v.ua/laws/show/1556-18\#Text (дата звернення: 17.11.2020).
} 
Як результат, закордонна освіта, у т. ч. юридична, продовжує вабити українців. 3 метою формування методичних рекомендацій щодо покращення системи юридичної освіти в Україні продовжуємо аналізувати думки майбутніх юристів і молодих юристів, які вже здобули юридичну освіту у вітчизняних вишах.

Закордонна освіта багатьох юристів-початківців цікавить як трамплін до подальшого кар'єрного росту. Наприклад, за дослідженням «ЮГ», Святославу Грігорашу навчання за кордоном допомогло отримати роботу в одній із провідних юридичних фірм Sayenko Kharenko, де у нього $€$ можливість працювати у сфері корпоративного права і застосовувати отримані університетські знання на практиц 19 .

Після повернення в Україну Іван Чайка побачив, що з'явився пожвавлений попит на юристів зі знанням мов, іноземною освітою та практичним досвідом за кордоном. Маючи такий «бекграунд», значну частину роботи закордонного юриста може зробити й український (особливо із двома адвокатськими посвідченнями). Молодий правник вважає, що клієнт тільки подякує за зекономлений рахунок.

Крім того, за словами Івана Чайки, розуміння тонкощів іноземної правової системи, особливо прецедентного права, принципів роботи їхніх юридичних спеціалістів і навіть менталітету, надає також і нематеріальні переваги для українського юриста. Серед таких переваг Іван Чайка, котрий обіймає посаду головного юриста в організації SUNTRI, називає можливість побудови більш складних мультиюрисдикційних систем, дієвий особистий захист i захист українського бізнесу чи громадян за кордоном, нетворкінг ${ }^{20}$, розширення клієнтської та партнерської бази.

Михайло Іскра зазначає, що не всі спеціалізації, здобуті за кордоном, мають пряме застосування в Україні. Наприклад, його спеціалізація право Свропейського Союзу (далі - ЄС). $50 \%$ із того, що Михайло вивчав, потрібно для юриста, який працюватиме у юридичній фірмі в Брюсселі. Інші $50 \%$ - загальнотеоретичні знання про $€ C$, що, хоч і цікаві, але не несуть практичного навантаження. Проте, за словами Михайла, це не означає, що закордонний диплом нічого не дає. Навчання за кордоном розвиває світогляд, робить молодих юристів більш впевненим у собі, дає велику перевагу над іншими кандидатами та підсилює спроможність мислити нестандартно.

19 Study abroad: закордонна освіта очима українських правників. URL: https://yur-gazeta.com/ publications/practice/inshe/study-abroad-zakordonna-osvita-ochima-ukrayinskih-pravnikiv.html (дата звернення: 11.11.2020).

${ }^{20}$ Нетворкінг - соціальна і професійна діяльність, спрямована на те, щоб за допомогою кола друзів і знайомих максимально швидко й ефективно вирішувати складні життєві завдання і бізнес-питання. В основі нетворкінгу лежить вибудовування довірчих і довгострокових відносин із людьми та взаємодопомога. 
Студентка Варшавського університету Марина Мокрецька вважає, що випускники закордонних вишів мають більшу конкурентоспроможність на ринку праці серед компаній як в Україні, так і за кордоном. Від наявності іноземного диплому часто може залежати заробітна плата, посада, на яку претендує особа, та компанія, до якої бажає потрапити випускник, але наявність іноземного диплому може мати вплив на все це за умови, що особа вміє використовувати здобуті знання та навики.

Із цим важко не погодитися. Невміння застосувати теоретичні знання у повсякденній роботі, під час виконання покладених обов'язків (повноважень), невміння знайти «точку» прикладання отриманих знань змушує молодих юристів змінювати фах. Щоб цього не відбувалося, враховуючи європейський досвід, у вітчизняній системі юридичної освіти доцільно більш активно запроваджувати обов'язкові тренінги як для студентів, так і для викладачів.

Для студентів-юристів, безсумнівно, корисною буде дуальна форма здобуття вищої освіти ${ }^{21}$, тобто тривалі (рік і більше) навчання у практичних підрозділах, юридичних фірмах, адвокатських і нотаріальних конторах тощо.

Викладачам юридичних дисциплін, як учасникам навчального процесу, щоб враховувати ті вимоги, які роботодавці ставлять до випускників юридичних вишів, також необхідно постійно підвищувати свій фаховий рівень, як паралельно зі студентами, що проходять практику (навчання на робочому місці), так і вивчаючи досвід колег інших вишів на території України та поза іï межами. 3 цією метою вишам доцільно знаходити можливість i більш активно запроваджувати програми академічної мобільності ${ }^{22}$ для студентів і викладачів. Обмін студентами та викладачами може здійснюватися як під час вивчення класичних юридичних дисциплін (наприклад, таких як кримінальне право, цивільне право, господарське право, екологічне право тощо), так і під час вивчення окремих фахових (спеціальних) правових програм (навчальних дисциплін).

Щодо удосконалення вітчизняної системи обміну студентами та викладачами у процесі підготовки юристів і вибору іноземного навчального закладу 3 метою отримання юридичної освіти українськими студентами

\footnotetext{
${ }^{21}$ Дуальна форма здобуття вищої освіти - це спосіб здобуття освіти здобувачами денної форми, що передбачає навчання на робочому місці на підприємствах, в установах та організаціях для набуття певної кваліфікації обсягом від 25 до $60 \%$ загального обсягу освітньої програми на основі договору. Навчання на робочому місці передбачає виконання посадових обов'язків відповідно до трудового договору (ч. 6 ст. 49 Закону України «Про вищу освіту» від 1 липня 2014 р. № 1556-VII (із змінами і доповненнями)). URL: https://zakon.rada.go3v.ua/laws/show/1556-18\#Техt (дата звернення: 17.11.2020).

${ }^{22}$ Академічна мобільність - можливість учасників освітнього процесу навчатися, викладати, стажуватися чи проводити наукову діяльність в іншому закладі вищої освіти (науковій установі) на території України чи поза їі межами (п. 2 ч. 1 ст. 1 Закону України «Про вищу освіту» від 1 липня 2014 р. № 1556-VII (із змінами і доповненнями). URL: https://zakon.rada.go3v.ua/laws/show/1556-18\#Text (дата звернення 17.11.2020)
} 
(абітурієнтами), на нашу думку, цінними будуть поради Ярослава Любченка, який отримав ступінь магістра на факультеті підготовки юристів для Міністерства закордонних справ Національного юридичного університету імені Ярослава Мудрого, а нині працює юристом проектного oфicy ProZorro (Продажі) $)^{23}$. Він навчався за кордоном на різних фахових правових програмах у п’яти країнах Свропи (Швейцарії, Естонії, Франції, Хорватії, Латвіі), і для тих, хто бажає навчатися в іноземному виші, дає найголовнішу пораду: необхідно завчасно готуватися до подачі документів. Справа тут, за словами Ярослава, не лише у правильному написанні мотиваційного листа (за змістом і без граматичних та орфографічних помилок) та обранні «рекомендаторів» (яких також слід обирати обережно, адже багато хто не володіє англійською або не матиме часу на заповнення онлайн-анкети щодо апліканта ${ }^{24}$ ). Важливим етапом є і підготовка резюме, що має відображати участь кандидата у різних проектах стосовно програми, на яку здійснюється подання документів.

Респондент зупинився також і на відмінностях отримання юридичної освіти в Україні та за пї межами. Основна відмінність зарубіжних університетів порівняно з вітчизняними - орієнтація на практику, а не теорію. Так, наприклад, Ризька вища школа права, де навчався Ярослав, кожного тижня організовувала різноманітні заходи для студентів i викладачів. Зокрема, до університету приїзжав посол Японії та розповідав про плани країни на майбутнє, географічних сусідів і ставлення до праці. На думку молодого юриста, такі зустрічі $є$ набагато кориснішими, ніж тонни найкращих посібників, оскільки дають можливість дізнатися про практичні аспекти, розвинути комунікаційні навички, завести нові цікаві знайомства. Запам'ятався українському студентові також курс із міжнародного права. Цей курс викладав професор Tјасо T. van den Hout, який 9 років був секретарем Постійного арбітражного суду в Гаазі (Permanent Court of Arbitration), а також дипломатом у Нідерландах. Професор ніколи не писав дисертацій, але вже давно викладає в університетах i, враховуючи його практичний досвід, на думку Ярослава, слухати такі лекції неймовірно цікаво.

Викладене свідчить про те, що сучасні студенти надають перевагу лекторам, котрі мають практичний досвід. На нашу думку, українські студенти, зокрема майбутні юристи, також не відмовилися б від подібної організації навчального процесу. На жаль, більшість вишів України

\footnotetext{
${ }^{23}$ Study abroad: закордонна освіта очима українських правників. URL: https://yur-gazeta.com/ publications/practice/inshe/study-abroad-zakordonna-osvita-ochima-ukrayinskih-pravnikiv.html (дата звернення: 11.11.2020).

${ }^{24}$ Аплікант - людина, яка подала заяву на участь у певній події.
} 
віддають перевагу лекторам, які працюють у навчальному закладі на постійній основі, мають наукові ступені кандидатів і докторів наук, вчені звання доцентів і професорів. 3 цими лекторами не потрібно додатково узгоджувати (змінювати) розклад, вирішувати питання щодо погодинної оплати лекцій та інші питання організації навчального процесу. Побажання студентів вишом не враховуються.

Ярослав також звернув увагу на відмінну від української методику проведення занять. За кордоном немає лекцій у традиційному для України розумінні, коли група студентів під запис слухає монотонне читання лектором завчасно підготовленого тексту. Натомість студенти приходять на заняття вже підготовленими (тема заняття оголошується заздалегідь), із переліком питань, які виявилися незрозумілими чи які студент бажає виставити на обговорення. Саме ж заняття зазвичай проходить у формі жвавої, а головне - цікавої дискусії. Лектор тут виступає лише модератором ${ }^{25}$.

Як показує власний педагогічний досвід викладацької роботи в університеті, не кожен із сучасних викладачів навчальних дисциплін юридичноправового спрямування готовий до такої форми (методики) проведення занять, зокрема читання лекцій. Хоча вона позитивно сприймається студентами i, на нашу думку, застосування цієї методики викладання правових дисциплін у національній вищій школі значно покращило б рівень засвоєння знань студентами.

Поділяємо думку Ярослава, котрий впевнений, що такі підходи варто запозичити й Україні - не лише на рівні вищої освіти, а й у школах.

\section{ВИСНОВКИ}

Проведене дослідження, власний викладацький i практичний досвід дозволяють нам зробити такі висновки та надати методичні рекомендації щодо впровадження досвіду країн $Є \mathrm{C}$ у систему підготовки юристів в Україні:

- система вищої освіти в Україні, зокрема процес підготовки юристів, потребують системних змін. Запровадження іноземного досвіду без урахування вітчизняних традицій не досягає поставленої мети, погіршуючи якість підготовки вітчизняних фахівців, у т. ч. юристів;

- Міністерство освіти і науки України, покладаючись на автономність вишів, не повинно дозволяти підготовку юристів за освітніми програмами,

\footnotetext{
${ }^{25}$ Study abroad: закордонна освіта очима українських правників. URL: https://yur-gazeta.com/ publications/practice/inshe/study-abroad-zakordonna-osvita-ochima-ukrayinskih-pravnikiv.html (дата звернення: 11.11.2020).
} 
які не відповідають встановленим стандартам ${ }^{26}$. Зокрема, це стосується переліку обов'язкових дисциплін, необхідних для підготовки юриста. Стандарти підготовки юристів необхідно періодично перезатверджувати, оновлюючи зміст стандарту відповідно до вимог практики та европейського досвіду підготовки юристів;

- організація навчального процесу, зміст навчання, система оцінювання знань майбутніх юристів і підбір науково-педагогічного складу прерогатива вишу, але вони повинні бути студенто- та практикоорієнтованими. Такий підхід породжуватиме здорову конкуренцію, підвищуватиме авторитет і престиж не тільки юридичних, але й інших національних вишів;

- готовність і спроможність викладача (лектора) опанувати нові методи викладання, використовувати сучасні технології у навчальному процесі, краще за все оцінять студенти шляхом бажання чи небажання вивчати запропоновані викладачем дисципліни.

\section{АНОТАЦІЯ}

Удосконалення системи підготовки юристів в Україні було кінцевою метою нашого дослідження. Вивчення досвіду організації системи юридичної освіти у країнах $€ C$ дозволило зробити висновки та сформулювати методичні рекомендації щодо удосконалення процесу підготовки юристів в України:

- система вищої освіти в Україні, зокрема процес підготовки юристів, потребують системних змін. Запровадження іноземного досвіду без урахування вітчизняних традицій не досягає поставленої мети, погіршуючи якість підготовки вітчизняних фахівців, у т. ч. юристів;

- Міністерство освіти і науки України, покладаючись на автономність вишів, не повинне дозволяти підготовку юристів за освітніми програмами, які не відповідають встановленим стандартам. Зокрема, це стосується переліку обов'язкових дисциплін, необхідних для підготовки юриста. Стандарти підготовки юристів доцільно періодично перезатверджувати, оновлюючи зміст стандарту відповідно до вимог практики та світового, у т. ч. європейського, досвідом організації навчального процесу юристів;

\footnotetext{
${ }^{26}$ Про затвердження стандарту вищої освіти за спеціальністю 081 «Право» для другого (магістерського) рівня вищої освіти : наказ Міністерства освіти і науки України від 17 серпня 2020 р. № 1053. URL: https://mon.gov.ua/storage/app/media/vyshcha/standarty/2020/08/081-pravo-magistr.pdf (дата звернення: 20.11.2020); Про затвердження стандарту вищої освіти за спеціальністю 081 «Право» для першого (бакалаврського) рівня вищої освіти : наказ Міністерства освіти і науки України від 12 грудня 2018 р. № 1379. URL: https://mon.gov.ua/storage/app/media/vishcha-osvita/zatverdzeni\%20standarty/12/21/081-pravobakalavr.pdf (дата звернення: 20.11.2020).
} 
- організація навчального процесу, зміст навчання, система оцінювання знань майбутніх юристів і підбір науково-педагогічного складу прерогатива вишу, але вони мають бути студенто- та практико-орієнтованими. Такий підхід породжуватиме здорову конкуренцію, підвищуватиме авторитет і престиж не тільки юридичних, але й інших національних вишів;

- готовність і спроможність викладача (лектора) опанувати нові методи викладання, використовувати сучасні технології у навчальному процесі краще за все оцінять студенти шляхом бажання чи небажання вивчати запропоновані викладачем дисципліни й опановувати професію юриста в Україні, а не за їі межами.

\section{ЛІТЕРАТУРА}

1. Про рішення Ради національної безпеки і оборони України від 14 вересня 2020 р. «Про Стратегію національної безпеки України» : Указ Президента України від 14 вересня 2020 p. № 392/2020. URL: https://zakon.rada.gov.ua/laws/show/392/2020\#Text (дата звернення: 11.11.2020).

2. Престиж юридичної професії. URL: https://prezi.com/admedxvk14bk/ presentation/ (дата звернення: 11.11.2020).

3. Study abroad: закордонна освіта очима українських правників. URL: https://yur-gazeta.com/publications/practice/inshe/study-abroad-zakordonnaosvita-ochima-ukrayinskih-pravnikiv.html (дата звернення: 11.11.2020).

4. Довідник ВН3. URL: http://osvita.ua/vnz/guide/search-17-0-0-147-0.html (дата звернення: 12.11.2020).

5. Тертишник В.М. Кримінальний процес України. Загальна частина : підручник. Київ : Алерта, 2014. 440 с.

6. Додаток III: Загальна Рамка кваліфікацій Європейського простору вищої освіти (редакція 2018 р.). URL: https://www.google.com/search?q= chrome..69i57\&sourceid=chrome\&ie=UTF-8 (дата звернення: 14.11.2020).

7. Про вищу освіту : Закон України від 1 липня 2014 р. № 1556-VII (із змінами i доповненнями). URL: https://zakon.rada.go3v.ua/laws/show/ 1556-18\#Tеxt (дата звернення: 17.11.2020).

8. Про затвердження стандарту вищої освіти за спеціальністю 081 «Право» для другого (магістерського) рівня вищої освіти : наказ Міністерства освіти і науки України від 17 серпня 2020 p. № 1053. URL: https://mon.gov.ua/storage/app/media/vyshcha/standarty/2020/08/ 081-pravo-magistr.pdf (дата звернення: 20.11.2020). 
9. Про затвердження стандарту вищої освіти за спеціальністю 081 «Право» для першого (бакалаврського) рівня вищої освіти : наказ Міністерства освіти і науки України від 12 грудня 2018 р. № 1379. URL: https://mon.gov.ua/storage/app/media/vishcha-osvita/zatverdzeni\%20 standarty/12/21/081-pravo-bakalavr.pdf (дата звернення: 20.11.2020).

\section{Information about author:}

Chyhryna H. L.,

Ph.D. in Law, Associate Professor, Professor at the Financial Investigations' Department University of State Fiscal Service of Ukraine 31, Universytetska str., Irpin, Kyiv region, 08201, Ukraine 